\title{
High genetic diversity and mixing of coastal horseshoe crabs (Tachypelus gigas) across major habitats in Sundaland, Indonesia
}

\author{
Naila Khuril Aini ${ }^{1}$, Yusli Wardiatno ${ }^{2,3}$, Hefni Effendi ${ }^{2,3}$, Ali Mashar ${ }^{2}$, Hawis Madduppa ${ }^{\text {Corresp. } 4,5}$ \\ ${ }^{1}$ Study Program of Aquatic Resources, Department of Aquatic Resources Management, Faculty of Fisheries and Marine Sciences, Graduate School, Institut \\ Pertanian Bogor, Bogor, Jawa Barat, Indonesia \\ 2 Department of Aquatic Resources Management, Faculty of Fisheries and Marine Sciences, Institut Pertanian Bogor, Bogor, Jawa Barat, Indonesia \\ 3 Environmental Research Center, Institut Pertanian Bogor, Bogor, Indonesia \\ 4 Department of Marine Science and Technology, Faculty of Fisheries and Marine Sciences, Institut Pertanian Bogor, Bogor, Jawa Barat, Indonesia \\ 5 Oceanogen Environmental Biotechnology Laboklinikum, Bogor, Indonesia \\ Corresponding Author: Hawis Madduppa \\ Email address: hawis@apps.ipb.ac.id
}

Species with limited dispersal abilities are often composed of highly genetically structured populations across small geographic ranges. This study aimed to investigate the haplotype diversity and genetic connectivity of the coastal horseshoe crab (Tachypleus gigas) in Indonesia. To achieve this, we collected a total of 91 samples from six main $T$. gigas habitats: Bintan, Balikpapan, Demak, Madura, Subang, and Ujung Kulon. The samples were amplified using primers for mitochondrial (mt) AT-rich region DNA sequences. The results showed 34 haplotypes, including seven shared and 22 unique haplotypes, across all localities. The pairwise genetic differentiation $\left(F_{\mathrm{ST}}\right)$ values were low (0 to 0.13$)$ and not significantly different ( $p>0.05$ ), except among samples from Ujung Kulon-Madura and Kulon-Subang $(p<0.05)$. Additionally, the analysis of molecular variance (AMOVA) showed the most variation within populations (95.23\%) compared to less among populations (4.77\%). The haplotype network showed evidence of shared haplotypes between populations. Tajima's $D$ and Fu's $F_{\mathrm{s}}$ test values indicated a population expansion. Our results showed a low level of differentiation, suggesting a single stock and high connectivity. Therefore, a regionally-based conservation strategy is recommended for the coastal horseshoe crab in Indonesia. 
1 High genetic diversity and mixing of coastal

2 horseshoe crabs (Tachypelus gigas) across major

3 habitats in Sundaland, Indonesia

4

5

6

7

8

9

10

11

12

13

14

15

16

17

18

19

20

21

22

23

24

25

26

27

28

29

30

31

32

33

34

35

36

37

38

39

40

41

42

43

44

45

\author{
Naila Khuril Aini ${ }^{1}$, Yusli Wardiatno ${ }^{2,3}$, Hefni Effendi ${ }^{2,3}$, Ali Mashar ${ }^{2}$, Hawis Madduppa ${ }^{4,5}$ \\ ${ }^{1}$ Study Program of Aquatic Resources in the Department of Aquatic Resources Management, \\ Faculty of Fisheries and Marine Sciences, Graduate School of Institut Pertanian Bogor, Bogor, \\ Indonesia \\ 2Department of Aquatic Resources Management, Faculty of Fisheries and Marine Sciences, \\ Institut Pertanian Bogor, Bogor, Indonesia \\ ${ }^{3}$ Environmental Research Center, Institut Pertanian Bogor, Bogor, Indonesia \\ ${ }^{4}$ Department of Marine Science and Technology, Faculty of Fisheries and Marine Sciences, \\ Institut Pertanian Bogor, Bogor, Indonesia \\ ${ }^{5}$ Oceanogen Environmental Biotechnology Laboklinikum, Bogor, Indonesia \\ Corresponding Author: \\ Hawis Madduppa ${ }^{4}$ \\ Dramaga, Bogor, Indonesia \\ Email address: hawis@apps.ipb.ac.id
}

\title{
Abstract
}

Species with limited dispersal abilities are often composed of highly genetically structured populations across small geographic ranges. This study aimed to investigate the haplotype diversity and genetic connectivity of the coastal horseshoe crab (Tachypleus gigas) in Indonesia. To achieve this, we collected a total of 91 samples from six main T. gigas habitats: Bintan, Balikpapan, Demak, Madura, Subang, and Ujung Kulon. The samples were amplified using primers for mitochondrial (mt) AT-rich region DNA sequences. The results showed 34 haplotypes, including seven shared and 22 unique haplotypes, across all localities. The pairwise genetic differentiation $\left(F_{\mathrm{ST}}\right)$ values were low $(0$ to 0.13$)$ and not significantly different $(p>0.05)$, except among samples from Ujung Kulon-Madura and Kulon-Subang $(p<0.05)$. Additionally, the analysis of molecular variance (AMOVA) showed the most variation within populations $(95.23 \%)$ compared to less among populations (4.77\%). The haplotype network showed evidence of shared haplotypes between populations. Tajima's $D$ and Fu's $F_{\mathrm{S}}$ test values indicated a population expansion. Our results showed a low level of differentiation, suggesting a single stock and high connectivity. Therefore, a regionally-based conservation strategy is recommended for the coastal horseshoe crab in Indonesia.

\section{Introduction}

High rates of gene flow are common in marine organisms that are spread across large geographic ranges (Palumbi, 1994; Crandall et al., 2019). Several marine organisms also exhibit low levels of genetic differentiation across large geographic scales (Avise, 2000). Population structures are affected by genetic drift, strong post-settlement selection (Hedgecock, 1986), and

Peer) reviewing PDF | (2020:10:54456:3:0:NEW 14 Jun 2021) 
46

47

48

49

50

51

52

53

54

55

56

57

58

59

60

61

62

63

64

65

66

67

68

69

70

71

72

73

74

75

76

77

78

79

80

81

82

83

84

85

86

87

88

89

90

91

spatial-landscape patterns (Johnson \& Black, 1998; Watts \& Johnson, 2004). Species with limited dispersal abilities are often composed of highly genetically structured populations with small geographic ranges (Collin, 2001). This creates opportunities to compare the depths and positions of intraspecific genetic differentiation when using location as an extrinsic factor (Bernardi \& Talley, 2000).

Horseshoe crabs, an interesting group of marine organisms considered "living fossils" (Eldredge \& Stanley 1984), have been extant for almost 500 million years. There are four extant species of horseshoe crabs: the American horseshoe crab (Limulus polyphemus) found along the eastern coast of North America from Maine to Mexico (Walls et al., 2002; Rutecki et al., 2004), and three Asian horseshoe crabs species (the mangrove horseshoe crab [Carcinoscorpius rotundicauda], the coastal horseshoe crab [Tachypleus gigas], and the tri-spined horseshoe crab [Tachypleus tridentatus]) (John et al., 2018; Vestbo, 2018) that are sporadically distributed across Southeast Asia and Japan. They are ancient marine arthropods that exhibit life-histories and habitat preferences that suggest a restricted dispersal ability (Sekiguchi, 1988). The Asian species are found in Indonesian coastal waters, dispersed around Sumatra, Java, Kalimantan, and Sulawesi (Rubiyanto, 2012; Mashar et al., 2017; Meilana et al., 2016).

Throughout their life cycle, horseshoe crabs are highly dependent on environmental conditions in coastal habitats. Most research suggests that they are declining both locally and regionally due to over-harvesting for food and biomedicine, and coastal development (Itow, 1993; Botton, 2001; Chen et al., 2004) and the loss of suitable spawning grounds. T. gigas was once relatively common along the northern Java Sea. However, coastal and mangrove horseshoe crab populations have an undetermined conservation status due to insufficient data (John et al., 2021). Furthermore, most population genetic studies on horseshoe crabs have focused on the American horseshoe crab, with little attention paid to the Asian horseshoe crab (Pierce et al., 2000; King et al., 2004; King et al., 2005; Yang et al., 2007; Rozihan \& Ismail 2011; King et al., 2015). Therefore, this study examined the genetic diversity, connectivity, and population structure of coastal horseshoe crabs by screening an AT-rich region of mitochondrial DNA, an established genetic marker for arthropods (Brehm et al., 2001). Our aim was to use genetic evidence to facilitate horseshoe crab conservation efforts in Indonesia.

\section{Materials \& Methods Study area and sample collection}

With the help of a local fisherman, adult and juvenile $T$. gigas specimens were collected from shallow waters in six locations around Indonesia: Bintan, Balikpapan, Demak, Madura, Subang, and Ujung Kulon (Fig. 1). We collected the hemolymph from a total of $91 \mathrm{~T}$. gigas specimens between April 2019 and August 2020. There were eight, 14, 16, 13, 20, and 20 samples from Bintan Island (BT), Balikpapan (BP), Demak (DK), Madura (MD), Subang (SB), and Ujung Kulon (UK), respectively. The hemolymph was collected from each individual and immediately preserved in absolute ethanol. Field experiments were approved by the Research Council of the Study Program from IPB University (letter number 1426/IT3.F3.2/KP.03.03.2019).

\section{Genomic DNA extraction, amplification, and DNA sequencing}

Genomic DNA was isolated from each hemolymph sample following a Genomic DNA Mini Kit (Geneaid, New Taipe, Taiwan) according to the manufacturer's instructions. A fragment of the AT-rich region was amplified using a pair of primers, $\mathrm{Hb}-12 \mathrm{~S}$ (5'- 
92

93

94

95

96

97

98

99

100

101

102

103

104

105

106

107

108

109

110

111

112

113

114

115

116

117

118

119

120

121

122

123

124

125

126

127

128

129

130

131

132

133

134

135

136

137

GTCTAACCGCGGTAGCTGGCAC-3') and Hb-trna

(5'GAGCCCAATAGCTTAAATTAGCTTA-3'), designed from the mitochondrial genome of the American horseshoe crab (Lavrov et al., 2000). A 25- $\mu$ L PCR reaction was carried out with $12.5 \mu \mathrm{L}$ MyTaq HS Red Mix (Meridian Bioscience, OH, United States), $9 \mu \mathrm{L} \mathrm{ddH}_{2} \mathrm{O}, 1.25 \mu \mathrm{L}$ forward and reverse primer, and $1 \mu \mathrm{L}$ DNA template. The entire reaction mixture was amplified using a peqSTAR thermal cycler (Peqlab, Erlangen, Germany), following Yang et al.'s (2007) amplification steps. The mixture underwent pre-denaturation at $95^{\circ} \mathrm{C}$ for 3 mins, followed by 30 cycles of denaturation at $94^{\circ} \mathrm{C}$ for $30 \mathrm{sec}$, annealing at $50^{\circ} \mathrm{C}$ for $1 \mathrm{~min}$, extension at $72^{\circ} \mathrm{C}$ for 2 min, one cycle at $72^{\circ} \mathrm{C}$ for $2 \mathrm{~min}$, and $25^{\circ} \mathrm{C}$ for $5 \mathrm{~min}$. The PCR product was visualized using electrophoresis on a $1 \%$ agarose gel in TAE buffer with ethidium bromide at $100 \mathrm{~V}$ for $30 \mathrm{~min}$. After electrophoresis, the gel was placed under UV light for band detection to determine the presence of a DNA fragment. The DNA sequencing was performed by $1^{\text {st }}$ BASE DNA Sequencing Services, Selangor, Malaysia.

\section{Data analysis}

A total of 91 AT-rich region sequences were obtained, and MEGA X (Kumar et al., 2018) was used to generate multiple alignments of the edited sequences. Genetic diversity was measured using the number of haplotypes (Hn), haplotype diversity $(\mathrm{Hd})$ and nucleotide diversity $(\pi)$ using DNASp v6 (Rozas et al., 2017). The population structure was assessed using Wright's fixation index $\left(F_{\mathrm{ST}}\right)$ and analysis of molecular variance (AMOVA). The significance level threshold $(\alpha)$, used to determine the pattern of differentiation between locations, was 0.05 . The pairwise $F$-statistic $\left(F_{\mathrm{ST}}\right)$ was calculated as the genetic distance based on the population differences using DNASp v6 (Rozas et al., 2017). The haplotype network across populations was estimated using a median joining (MJ) network (Bandelt et al., 1999) and was calculated using Network v 4.6.1.0 based on haplotype data. The haplotype composition across all study areas was illustrated in a map to show distribution and genetic connectivity patterns across the populations. Tajima's $D(1989)$ and Fu's $F_{\mathrm{S}}(1997)$ statistical tests were used to assess the population equilibrium using the Arlequin v.3.5 program (Excoffier \& Lischer, 2010).

\section{Results}

\section{Genetic diversity}

We obtained a total of 91 AT-rich sequences of approximately $670 \mathrm{bp}$ across all sampling locations including Java (UK, SB, DK, and MD), Sumatra, Bintan and Borneo (Balikpapan). In total, 43 variable nucleotide sites and 34 haplotypes were observed. The haplotypes consisted of both unique (found only in certain locations) and common haplotypes (Table 1). The genetic diversity of the coastal horseshoe crab varied across sampling sites (Table 2). The percentage of $\mathrm{A}+\mathrm{T}$ composition at each location, which differed slightly, was approximately $81 \%$.

At a glance, the obtained haplotype diversity was high, ranging from $h=0.783$ to 0.945 with a mean gene diversity per population $h=0.935$. Conversely, the nucleotide diversity was relatively low in all locations, ranging from $\pi=0.004$ to 0.009 . The overall diversity was similar across populations. DK had the lowest haplotype and nucleotide diversity $(h=0.783, \pi=0.004)$. BP had the highest haplotype and nucleotide diversity $(h=0.945 \pi=0.009)$, followed by UK $(h$ $=0.942, \pi=0.005), \mathrm{SB}(h=0.926, \pi=0.005), \mathrm{MD}(h=0.910, \pi=0.006)$, and $\mathrm{BT}(h=0.892, \pi=$ 0.006) (Table 2).

\section{Population structure}


138

139

140

141

142

143

144

145

146

147

148

149

150

151

152

153

154

155

156

157

158

159

160

161

162

163

164

165

166

167

168

169

170

171

172

173

174

175

176

177

178

179

180

181

182

183

Pairwise $F_{\mathrm{ST}}$ values ranged from 0 to 0.13 across the populations (Table 3 ). Generally, the $F_{\mathrm{ST}}$ value among locations was not significantly different from zero $(p>0.05)$ with the exception of UK-MD and UK-SB, indicating the restricted gene flow among these populations. Populations with higher pairwise $F_{\mathrm{ST}}$ values included BT-MD $(p>0.05)$, BT-SB $(p>0.05)$, UK-MD $(p<0.05)$, and UK-SB $(p<0.05)$. The pairwise $F_{\mathrm{ST}}$ values of UK-BT, DB-DK, and SB-MD were effectively zero. Our AMOVA results showed that the majority of variation was found within $(95.23 \%)$ rather than among $(4.77 \%)$ populations (Table 4$)$.

\section{Population connectivity}

The relationship of the 34 haplotypes was illustrated using a median-joining network (Fig. 2). The haplotype network showed that there were shared haplotypes (H1, H3, H5, H6, H8, H9, and H18) across the geographic sites. $\mathrm{H} 3$ was the most common, and was identified in all populations except UK and including 15 individuals. $\mathrm{H} 5$ was found in 12 individuals from the BT, BP, DK, SB, and UK populations. However, specific haplotypes were only found in certain locations. The UK population had the highest number of specific haplotypes (seven). Meanwhile, BT had the lowest number of haplotypes (two) (Fig. 3).

We assessed historical demography based on mtDNA AT-rich region haplotype frequencies. There were shared haplotypes in all locations (Fig. 2). Furthermore, the Tajima's $D$ test values (Table 5) were negative across all populations, with the exception of DK, MD, and SB. They showed no significant $p$-values, indicating that there was no evidence of selection. Similarly, the Fu's $F$ s test results (Table 5) were negative (except in DK), with no significant $p$ values across all six populations. This indicated an excess number of haplotypes, as expected due to a recent population expansion.

\section{Discussion}

In this study, there was high haplotype diversity in six coastal horseshoe crab populations in the northern Java Sea, Bintan, and Balikpapan waters of Indonesia. There was also a high number of polymorphic sites (43, with 34 defined haplotypes) in Indonesian coastal horseshoe crab populations. The mean haplotype diversity $(h=0.935)$ was quite high, while nucleotide diversity $(\pi=0.006)$ was low across all populations. Similarly high haplotype diversity values were reported in T. gigas $(h=0.797 \pm 0.129$ and $\pi=0.058 \pm 0.001$; Rozihan \& Ismail, 2011) in Malaysia and tri-spined horseshoe crab (T. tridentatus) in Taiwan $(h=0.626 \pm 0.075$ and $\pi=$ $0.003 \pm 0.005$; Yang et al., 2007).

Previous studies reported generally high genetic diversity in coastal horseshoe crab (Rozihan \& Ismail 2011; Aini et al., 2020). Our results showed not only high genetic diversity, but also low nucleotide diversity. The high number of haplotypes indicates that these populations were large enough to maintain a high level of genetic diversity. These small differences are the signature of rapid demographic expansion from a small effective population size (Avise, 2000). Nucleotide diversity is a sensitive index when analyzing population genetic diversity (Nei \& Li, 1979), and is influenced by life-history characteristics, environmental heterogeneity, population size (Nei, 1987; Avise, 2000), fishing pressure (Madduppa et al., 2018), level of larval transport, and degree exchange with other populations (Timm et al., 2017). The rate of mitochondrial evolution and historical factors play an important role in determining genetic variability patterns (Grant et al., 2006; Xiao et al., 2009; Yamaguchi et al., 2010).

We detected low differentiation across populations (insignificant $F_{\text {ST }}$ values between 0 and 0.13 ), with exceptions between populations UK-MD and UK-SB. This result indicated that there 
184

185

186

187

188

189

190

191

192

193

194

195

196

197

198

199

200

201

202

203

204

205

206

207

208

209

210

211

212

213

214

215

216

217

218

219

220

221

222

223

224

225

226

227

228

229 was little subdivision across populations. Several studies suggested restricted dispersal abilities for horseshoe crabs regarding short-term tagging. However, some others explained that this crab has a wide dispersal abilities based on long-term studies. Individual distances up to $30 \mathrm{~km}$ have been observed in Malaysian crabs (Mohamad et al., 2019), while the movement abilities of trispined horseshoe crab did not exceed $150 \mathrm{~km}$ (Yang et al., 2007). Similarly, the American horseshoe crab in the Great Bay Estuary (USA) has a maximum mean annual linear distance ranging between $4.5 \mathrm{~km}$ and $9.2 \mathrm{~km}$ (Schaller et al., 2010). Studies by Swan (2005) over multiple years found that Limulus moved from 104 to $265 \mathrm{~km}$ from their release sites. Ecological observations showed that their hatched larvae swim freely for approximately 6 days and then settle in the bottom of shallow waters around their natal beaches (Shuster, 1982). However, larvae have a strong tendency to concentrate in inshore rather than offshore waters $(100-200 \mathrm{~km})$ (Botton \& Loveland, 2003), suggesting a limited ability for long-range dispersal between estuaries. Additionally, low $F_{\mathrm{ST}}$ levels reflect inter-population movement over mutigenerational intervals that short-term tagging studies cannot document. Long-term tagging studies have found that horseshoe crabs can move from $>5-500$ predominated $\mathrm{km} \mathrm{5-30} \mathrm{km} \mathrm{(Beekey} \mathrm{\&} \mathrm{Mattei,} \mathrm{2015),}$ and up to $767 \mathrm{~km}$ over their long lifetimes (E. Hallerman, 2020, personal communication). Longterm tagging study similar study by Rozihan \& Ismail (2011) reported that the crab's $F_{\text {ST }}$ value along the west coast of peninsular Malaysia ranges from $0.111-0.557$, indicating moderate to high genetic differentiation (Wright, 1978; Hartl \& Clark, 1977). Other reports in the area used microsatellite markers to find a $F_{\text {ST }}$ value between 0.144 and 0.846 .

There were only seven shared haplotypes among the 34 total haplotypes observed among all 91 samples. The median-joining network analysis indicated past population expansions with shared haplotypes among localities. Overall, relationship patterns at the mtDNA level showed little geographical structure. The haplotype network revealed recent demographic processes, but the small sample sizes also limited the possibility of observing the intermediate haplotypes inferred to exist in the network. Moreover, results of Tajima's $D$ and Fu's $F$ s tests indicated the occurrence of population expansion. Common haplotypes shared between localities also can be explained by the historical biogeography in this Southeast Asian region known as the Sunda Shelves, which includes Java, Sumatera, and Borneo. Historically, Sundaland experienced both dewatering and inundation during the Pleistocene period. Haplotype sharing in this study is attributed to breeding migration and dispersal of pelagic larvae, as well as the sharing of common ancestors (Frankham, 1996). The occurrence of many geographic site-specific haplotypes can be explained by the small sample size and perhaps historical isolation during the Last Glacial Maximum. Many species became isolated in refugia, and genetic differentiation and divergence occurred due to the retreat and dispersal of glacial ice sheets (Hewitt, 2000).

A proactive management approach regarding the Asian coastal horseshoe crab (T. gigas) in Indonesia should consider population genetics. High haplotype diversity that occurs with low nucleotide diversity has been associated with population growth or expansion after a period of low effective population growth (Grant \& Bowen, 1998). Our findings indicate that T. gigas in Indonesia have low genetic differentiation but high population connectivity and expansion. Therefore, our results suggest that there is a single stock of Indonesia coastal horseshoe crab. The best conservation strategy would be one that combines both local and regional management. To expand our knowledge base, an advanced population genetic analysis based on male and female horseshoe crabs and the nuclear genome (e.g., microsatellites or SNPs) should be conducted. This should also include expanding the scope of geographic sampling around Indonesia.

Peer) reviewing PDF | (2020:10:54456:3:0:NEW 14 Jun 2021) 
230

231

232

233

234

235

236

237

238

239

240

241

242

243

244

245

246

247

248

249

250

251

252

253

254

255

256

257

258

259

260

261

262

263

264

265

266

267

268

269

270

271

272

273

274

275

\section{Conclusion}

High genetic diversity and low levels of differentiation across coastal horseshoe crab ( $T$. gigas) populations in Indonesia indicated a single stock with high connectivity. A locally and regionally based conservation management method is suggested as a precautionary approach to conserving the Indonesian coastal horseshoe crab.

\section{Acknowledgements}

The authors are grateful to everyone who helped in the field work: local fishermen in all sampling areas, Dr. Qian Tang, Heri Saputro, Agus Alim Hakim, Rani Nuraisah, Siti Mira Rahayu, Ahmad Fauzi Ridwan, and Yunita Multi Cahya Ningrum.

\section{References}

Aini NK, Mashar A, Madduppa HH, Wardiatno Y. 2020. Genetic diversity of horseshoe crabs (Carcinoscorpius rotundicauda and Tachypleus gigas) in Demak, Madura and Balikpapan waters based on Random Amplified Polymorphic DNA marker. Journal of Natural Resources and Environmental Management 10(1). 124-137. DOI: 10.29244/jpsl.10.1.124137.

Avise JC. 2000. Phylogeography: The History and Formation of Species. Cambridge: Harvard University Press 447.

Bandelt H-J, Forster P, Röhl A. 1999. Median-joining networks for inferring intraspecific phylogenies. Molecular Biology and Evolution 16: 37-48. PMID: 10331250 DOI: 10.1093/oxfordjournals.molbev.a026036.

Beekey MA, Mattei JH. 2015. The mismanagement of Limulus polyphemus in Long Island Sound, U.S.A.: What are the characteristics of a population in decline? In: Carmichael RH, Botton ML, Shin PKS, Cheung SG, ed. Changing Global Perspectives on Horseshoe Crab Biology, Conservation and Management. Berlin: Springer, 433-461.

Bernardi G, Talley D. 2000. Genetic evidence for limited dispersal in the coastal California killifish, Fundulus parvipinnis. Journal of Experimental Marine Biology and Ecology 255: 187-199. DOI: 10.1016/S0022-0981(00)00298-7.

Brehm A, Harris DJ, Hernandez M, Cabrera V, Larruga J, Pinto F, Gonzalez AM. 2001. Structure and evolution of the mitochondrial DNA complete control region in the Drosophila subobscura subgroup. Insect Molecular Biology 10: 573-578. DOI: 10.1046/j.0962-1075.2001.00295.x.

Botton ML. 2001. The conservation of horseshoe crab: what can we learn from the Japanese experience ? In: Tanacredi TJ, ed. Limulus in the Limelight. New York: Kluwer Academic/Plenum, 41-51.

Botton ML, Loveland RE. 2003. Abundance and dispersal potential of horseshoe crab (Limulus polyphemus) larvae in the Delaware estuary. Estuaries 26(6): 1472-1479. DOI: $10.1007 / \mathrm{BF} 02803655$.

Chen CP, Yeh HY, Lin PF. 2004. Conservation of horseshoe crabs in Kinmen, Taiwan: strategies and practices. Biodiversity and Conservation 13: 1889-1904. DOI: 10.1023/B:BIOC.0000035868.11083.84.

Collin R. 2001. The effects of mode of development on phylogeography and population structure of North Atlantic Crepidula (Gastropoda: Calyptraeidae). Molecular Ecology 10: 22492262. PMID: 11555267 DOI: 10.1046/j.1365-294x.2001.01372.x. 
276

277

278

279

280

281

282

283

284

285

286

287

288

289

290

291

292

293

294

295

296

297

298

299

300

301

302

303

304

305

306

307

308

309

310

311

312

313

314

315

316

317

318

319

320

321

Crandall E, Riginos C, Bird C, Liggins L, Treml E, Beger M, Barber PH, Connolly SR, Cowman PF, DiBattista JD, Eble JA, Magnuson SF, Horne JB, Kochzius M, Lessios HA, Liu SYV, Ludt WB, Madduppa H, Pandolfi JM, Toonen RJ, Contributing Members of the Diversity of the Indo-Pacific Network, Gaither MR. 2019. The molecular biogeography of the IndoPacific: testing hypotheses with multispecies genetic patterns. Global Ecology and Biogeography 28(5): 943-96. DOI:10.1111/geb.12905.

Eldredge N, Stanley SM. 1984. Living Fossils. Berlin: Springer Publishing.

Excoffier L, Lischer HEL. 2010. Arlequin suite ver 3.5: A new series of programs to perform population genetics analyses under Linux and Windows. Molecular Ecology Resources 10: 564-567. DOI: 10. 1111/j.1755-0998.2010.02847.x PMID: 21565059.

Frankham R. 1996. Relationship of genetic variation to population size in wildlife. Conservation Biology 10(6): 1500-1508. DOI: 10.1046/j.1523-1739.1996.10061500.x.

$\mathrm{Fu}$ YX. 1997. Statistical tests of neutrality of mutations against population growth, hitchhiking and background selection. Genetics 147(2): 915-925. PMCID: PMC1208208.

Grant WS, Bowen BW. 1998. Shallow population histories in deep evolutionary lineages of marine fishes: insight from sardines and anchovies and lessons for conservation. Genetics 89: 415-426.

Grant WS, Spies IB, Canino MF. 2006. Biogeographic evidence for selection on mitochondrial DNA in north Pacific walleye pollock Theragra chalcogramma. Journal of Heredity 97(6): 571-580. DOI: 10.1093/jhered/es1033.

Hartl DL, Clark AG. 1997. Principles of Population Genetics, 3nd edn. Sunderland MA: Sinauer Associates, Inc.

Hedgecock R. 1986. Is gene flow from pelagic larval dispersal important in the adaptation and evolution of marine invertebrates? Bulltin of Marine Science 39(2): 550-565.

Hewitt G. 2000. The genetic legacy of the Quaternary ice ages. Nature 405: 907-913. DOI: $10.1038 / 35016000$.

Itow T. 1993. Crisis in the Seto Inland Sea: the decimation of the horseshoe crab. EMECS Newslett. 3: 10-11.

John BA, Nelson BR, Sheikh HI, Cheung SG, Wardiatno Y, Dash BP, Tsuchiya K, Iwasaki Y, Pati S. 2018. A review on fisheries and conservation status of Asian horseshoe crabs. Biodiversity and Conservation 27: 3573-3598. DOI: 10.1007/s10531-018-1650-7.

John A, Shin PKS, Botton ML, Gauvry G, Cheung SG, Laurie K. 2021. Conservation of Asian horseshoe crabs on spotlight. Biodiversity and Conservation 30: 253-256. DOI: 10.1007/s10531-020-02078-3.

Johnson MS, Black R. 1998. Increased genetic divergence and reduced genetic variation in populations of snail Bembicium vittatum in isolated tidal ponds. Heredity 80: 163-172. DOI: 10.1046/j.1365-2540.1998.00257.x.

King TL, Eackles MS. 2004. Microsatellite DNA markers for the study of horseshoe crab (Limulus polyphemus) population structure. Molecular Ecology Notes 4: 394-396. DOI: 10.1111/j.1471-8286.2004.00663.x.

King TL, Eackles MS, Spidle AP, Brockmann HJ. 2005. Regional differentiation and sex-biased dispersal among populations of the horseshoe crab (Limulus polyphemus). Transactions of the American Fisheries Society 134 (2): 441-465. DOI:10.1577/T04-023.1.

King TL, Eackles MS, Aunins AW, Brockmann HJ, Hallerman E, Brown BL. 2015. Conservation genetics of the American horseshoe crab (Limulus polyphemus): Allelic diversity, zones of genetic discontinuity, and regional differentiation. In: Carmichael RH,

Peer) reviewing PDF | (2020:10:54456:3:0:NEW 14 Jun 2021) 
322

323

324

325

326

327

328

329

330

331

332

333

334

335

336

337

338

339

340

341

342

343

344

345

346

347

348

349

350

351

352

353

354

355

356

357

358

359

360

361

362

363

364

365

366

Botton ML, Shin PKS, Cheung SG, ed. Changing Global Perspectives on Horseshoe Crab Biology, Conservation and Management. Berlin: Springer, 65-96.

Kumar S, Stecher G, Li M, Knyaz C, Tamura K. 2018. MEGA X: Molecular evolutionary genetics analysis across computing platforms. Molecular Biology and Evolution 35: 15471549. DOI: $10.1093 / \mathrm{molbev} / \mathrm{msy} 096$.

Lavrov DV, Boore JL, and Brown WM. 2000. The complete mitochondrial DNA sequence of the horseshoe crab Limulus polyphemus. Molecular Biology and Evolution 17: 813-824. DOI: 10.1093/oxfordjournals.molbev.a026360.

Madduppa HH, Timm J and Kochzius M. 2018. Reduced genetic diversity in the clown anemonefish Amphiprion ocellaris in exploited reefs of Spermonde Archipelago, Indonesia. Frontiers in Marine Science 5(80):1-8. DOI: 10.3389/fmars.2018.00080.

Mashar A, Butet NA, Juliandi B, Qonita Y, Hakim AA, Wardiatno Y. 2017. Biodiversity and distribution of horseshoe crabs in northern coast of Java and southern coast of Madura. IOP Conference Series: Earth and Environmental Sciences 54:1-8. DOI: 10.1088/17551315/54/1/012076.

Meilana L, Wardiatno Y, Butet NA, Krisanti M. 2016. Morphological character and molecular identification with COI gene marker of horseshoe crabs (Tachypleus gigas) at coastal waters of northern Java Island. Jurnal Ilmu dan Teknologi Kelautan Tropis 8(1): 145-158. DOI: $10.28930 /$ jitkt.v8i1.12651.

Nei M, Li WH. 1979. Mathematical model for studying genetic variation in terms of restriction endonucleases. Proceedings of the National Academy of Sciences of the United States of America 76(10): 5269-5273. DOI: 10.1073/pnas.76.10.5269.

Nei M. 1987. Molecular Evolutionary Genetics. New York: Columbia University Press.

Pierce JC, Tan G, Gaffney PM. 2000. Delaware Bay and Chesapeake Bay populations of the horseshoe crab Limulus polyphemus are genetically distinct. Estuaries 23: 690-698. DOI: $10.2307 / 1352895$.

Rozihan M, Ismail E. 2011. Genetic structure and haplotype diversity of Tachypleus gigas population along the west coast of Peninsular Malaysia inferred through mtDNA AT-rich region sequence analysis. Biotechnology 10(3): 298-302.

Rozas J, Ferrer-Mata A, Sanchez-DelBarrio JC, Guirao-Rico S, Librado P, Ramos-Onsins SE. 2017. DnaSP v6: DNA sequence polymorphism analysis of large datasets. Molecular Biology and Evolution 34: 3299-3302. DOI: 10.1093/molbev/msx248 PMID: 29029172.

Rubiyanto E. 2012. Study population of horseshoe crabs (Xiphosura) in peninsular Kuala Tungkal, the district of Tanjung Jabung Barat, Jambi. Master Thesis, University of Indonesia, Jakarta, Indonesia.

Rutecki D, Carmichael RH, Valiela I. 2004. Magnitude of harvest of Atlantic horseshoe crabs, Limulus polyphemus, in Pleasant Bay, Massachusetts. Estuaries 27: 179-187. DOI: 10.1007/BF02803374.

Schaller SY, Chabot CC, Watson WH. 2010. Seasonal movements of American horseshoe crabs Limulus polyphemus in the Great Bay Estuary, New Hampshire (USA). Current Zoology 56: 587-598. DOI: 10.1093/czoolo/56.5.587.

Sekiguchi K. 1988. Biology of Horseshoe Crabs. Tokyo: Science House.

Shuster CN Jr. 1982. A pictorial review of the natural history and ecology of the horseshoe crab Limulus polyphemus, with reference to other Limulidae. Progress in Clinical and Biological Research 81:1-52. PMID: 6750622.

Peer) reviewing PDF | (2020:10:54456:3:0:NEW 14 Jun 2021) 
367 368 369 370 371 372 373 374 375 376 377 378 379 380 381 382 383 384 385 386 387 388 389 390 391 392 393 394 395

Swan BL. 2005. Migrations of adult horseshoe crabs, Limulus polyphemus, in the middle Atlantic Bight: A 17-year tagging study. Estuaries 28: 28-40. DOI: 10.1007/BF02732751.

Tajima F. 1989. Statistical method for testing the neutral mutation hypothesis by DNA polymorphism. Genetics 123:585-595. PMID: 2513255; PMCID: PMC1203831.

Timm J, Kochzius M, Madduppa HH, Neuhaus AI, Dohna T. 2017. Small scale genetic population structure of coral reef organisms in Spermonde Archipelago, Indonesia. Frontiers in Marine Science 4: 294. DOI: 10.3389/fmars.2017.00294.

Vestbo S, Obst M, Quevedo Fernandez FJ, Intanai I, Funch P. 2018. Present and potential future distributions of Asian horseshoe crabs determine areas for conservation. Frontier Marine Science 5:164. DOI: 10.3389/fmars.2018.00164.

Walls EL, Berkson J, Smith SA. 2002. The horseshoe crab, Limulus polyphemus: 200 million years of existence, 100 years of study. Review Fisheries Sciences 10: 39-73. DOI: $10.1080 / 20026491051677$.

Watts RJ, Johnson MS. 2004. Estuaries, lagoons and enclosed embayments: habitats that enhance population subdivision of inshore fishes. Marine and Freshwater Research 55: 641-651. DOI: 10.1071/MF04051.

Wright S. 1978. Evolution and the genetics of population, variability within and among natural populations. Chicago: The University of Chicago Press.

Xiao YS, Zhang Y, Gao TX, Yanagimoto T, Yabe M, Sakurai Y. 2009. Genetic diversity in the mitochondrial DNA control region and population structure in the small yellow croaker Larimichthys polyactis. Environmental Biology of Fishes 85: 303-314. DOI: 10.1007/s10641-009-9497-0.

Yamaguchi K, Nakajima M, Taniguchi N. 2010. Loss of genetic variation and increased population differentiation in geographically peripheral populations of Japanese char Salvelinus leucomaenis. Aquaculture 308: S20-S27. DOI: 10.1016/j.aquaculture.2010.07.032.

Yang MC, Chen CA, Hsieh HL, Chen CP. 2007. Population subdivision of the tri-spine horseshoe crab, Tachypleus tridentatus, in Taiwan Strait. Zoological Science 24: 219-224. DOI: $10.2108 / \mathrm{zsj} .24 .219$. 
Figure 1

Sampling locations of Tachypleus gigas ; There were eight, 14, 16, 13, 20, and 20 samples from Bintan Island $(B T)=8$, Balikpapan $(B P)=14$, Demak $(D K)=16$, Madura $(\mathrm{MD})=13$, Subang $(\mathrm{SB})=20$ and Ujung Kulon $(\mathrm{UK})=20$

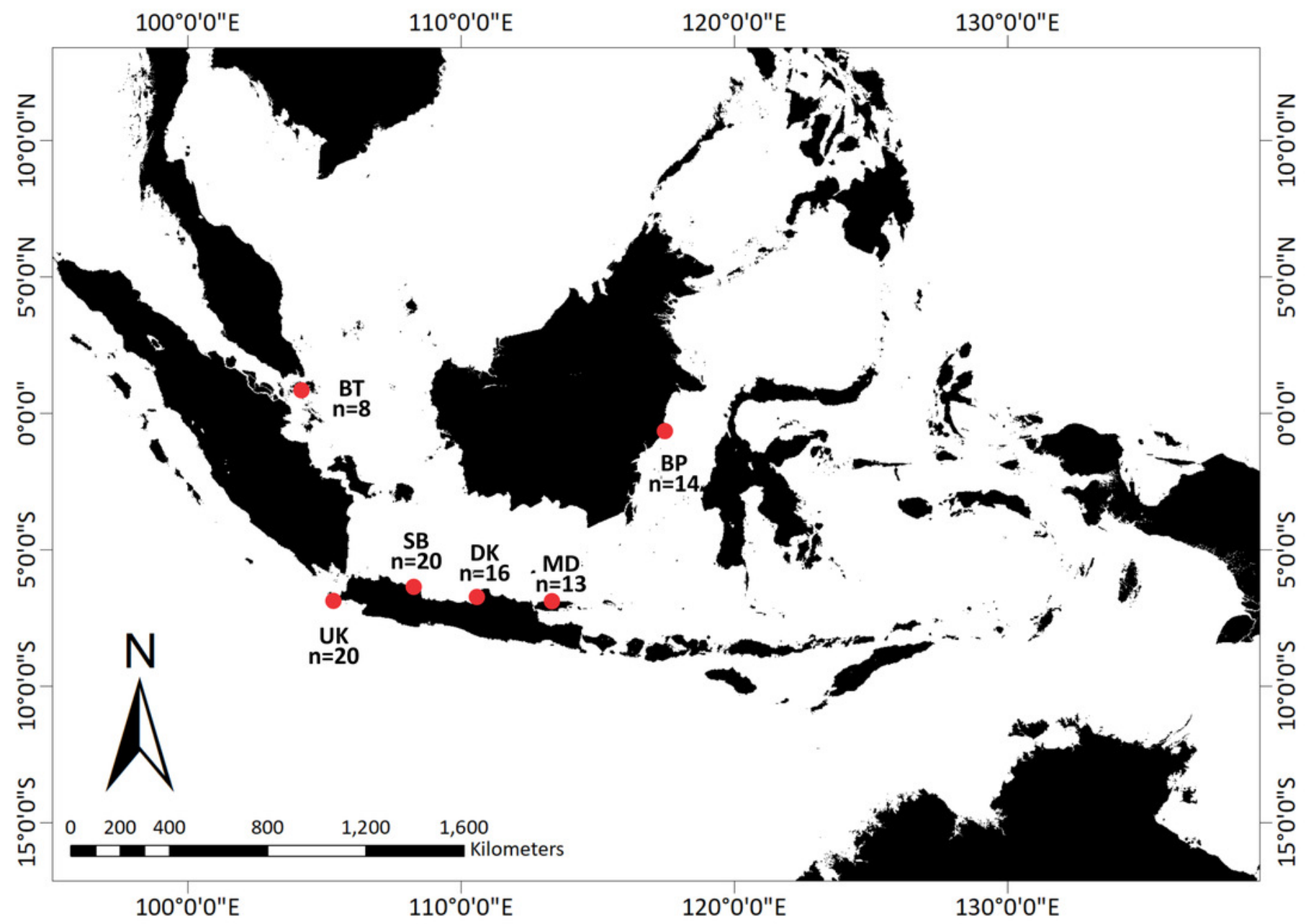


Figure 2

Haplotype network of Tachypleus gigas $(n=91)$ population in six locations around Indonesia, constructed with Median-Joining method
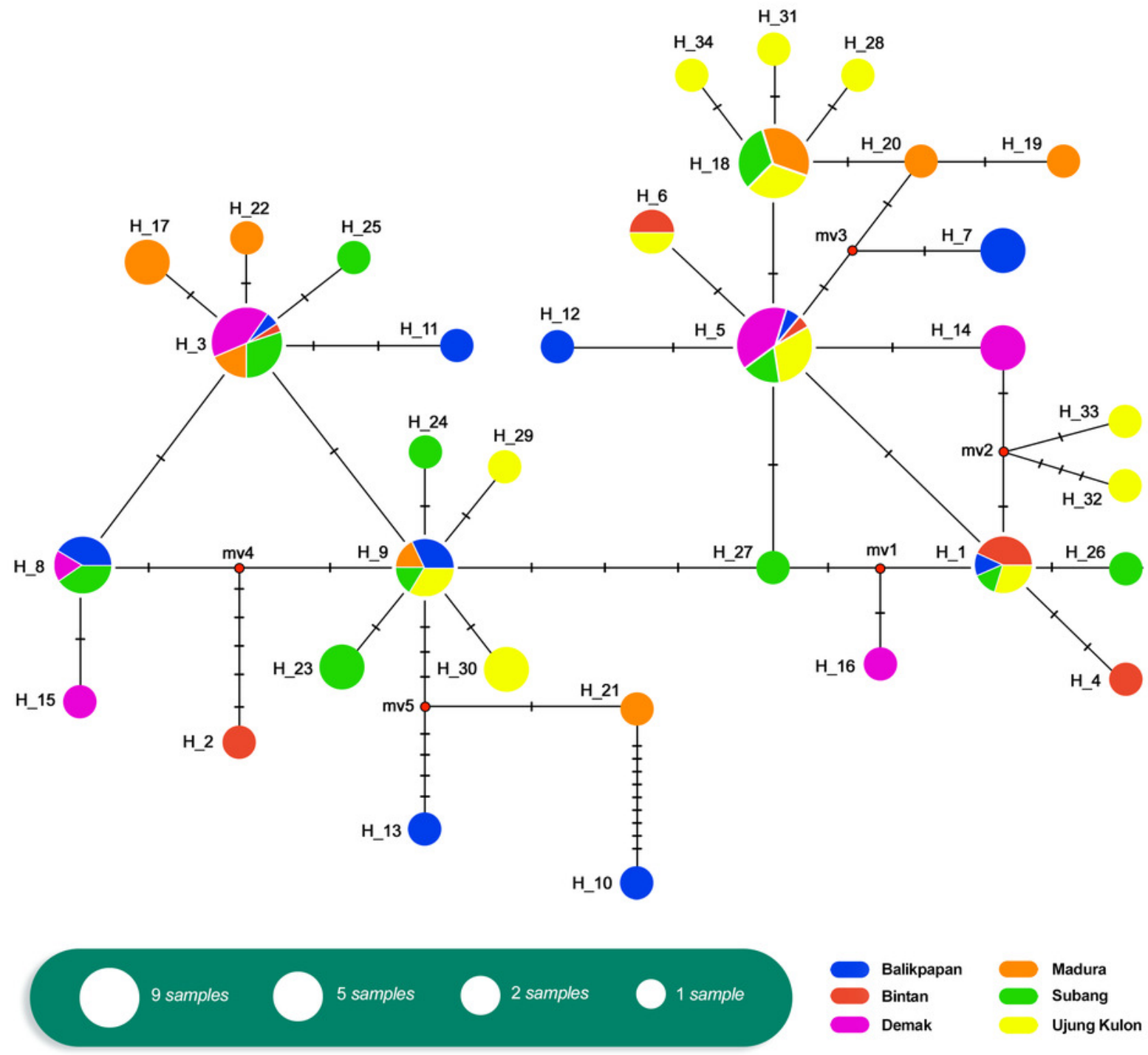
Figure 3

Distribution of 34 haplotypes of Tachypleus gigas population from six locations in around Indonesia

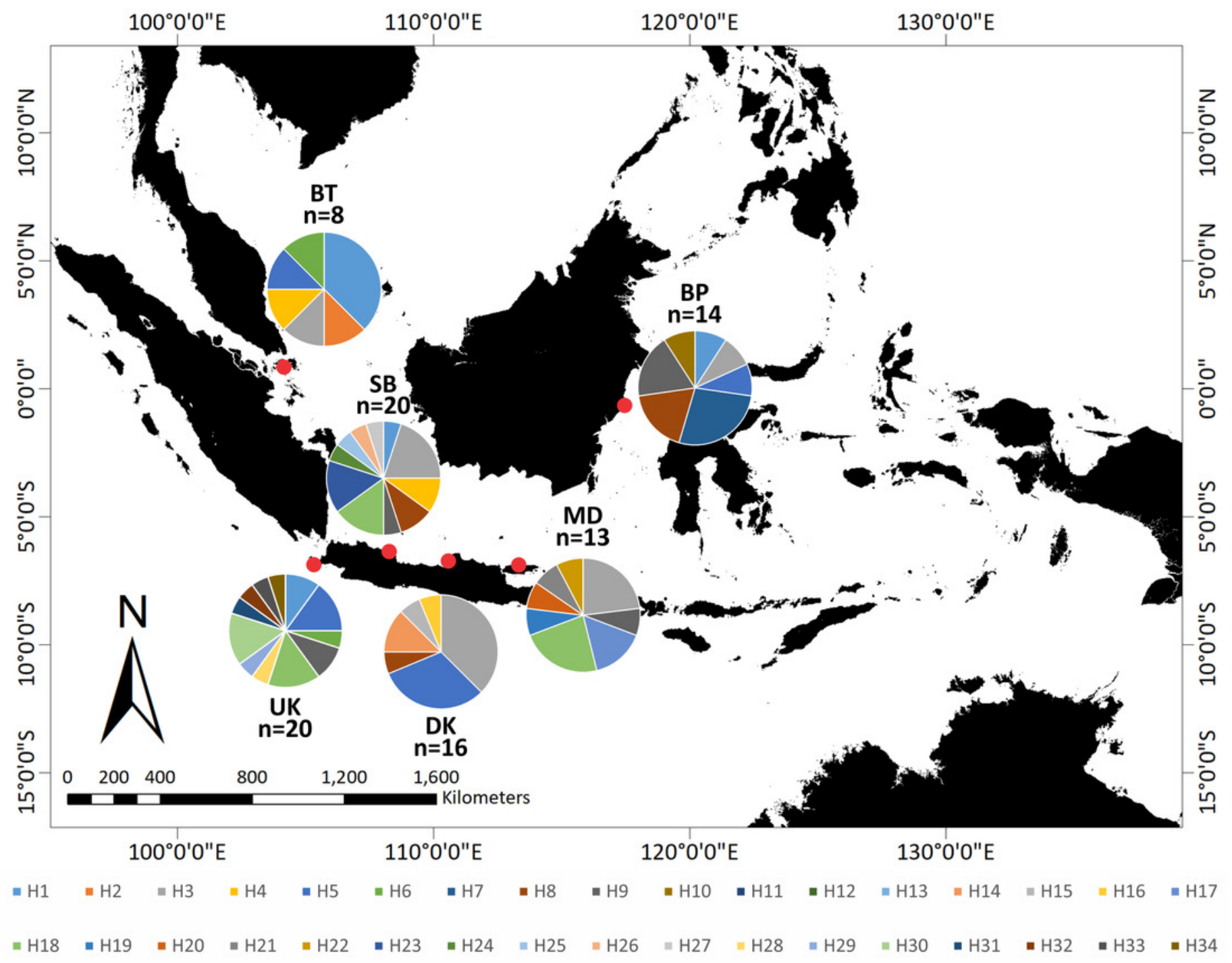




\section{Table $\mathbf{1}$ (on next page)}

Variable sites found in a fragment of the AT-rich region of Tachypleus gigas in each populations. Fourty three variable sites were found in a fragment of the AT-rich region in 91 horseshoe crabs defining 34 haplotypes ( $\mathrm{H} 1-\mathrm{H} 34)$ 


\section{Table 1:}

Variable sites found in a fragment of the AT-rich region of Tachypleus gigas in each populations. Fourty three variable sites were found in a fragment of the AT-rich region in 91 horseshoe crabs defining 34 haplotypes (H1-H34)

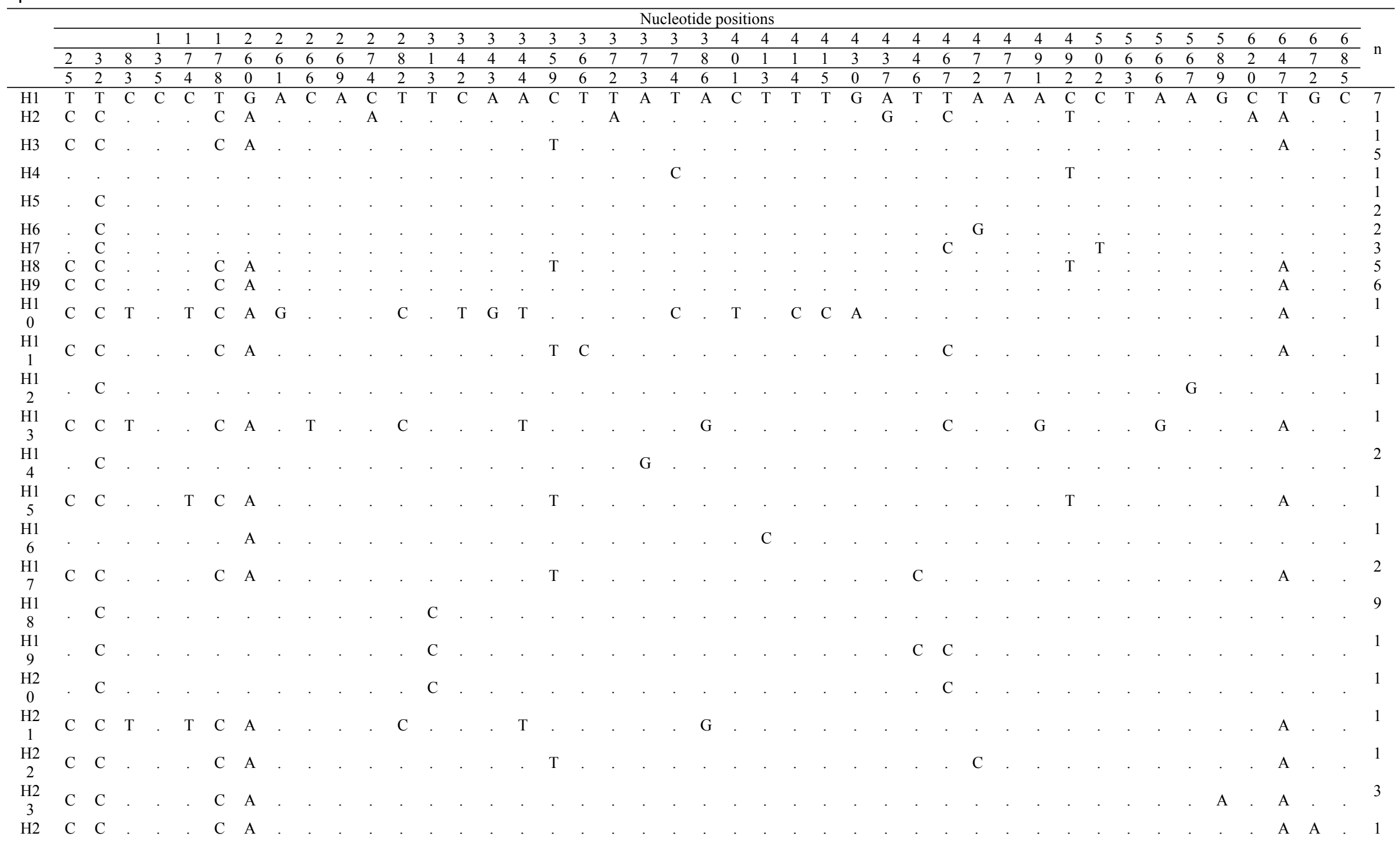




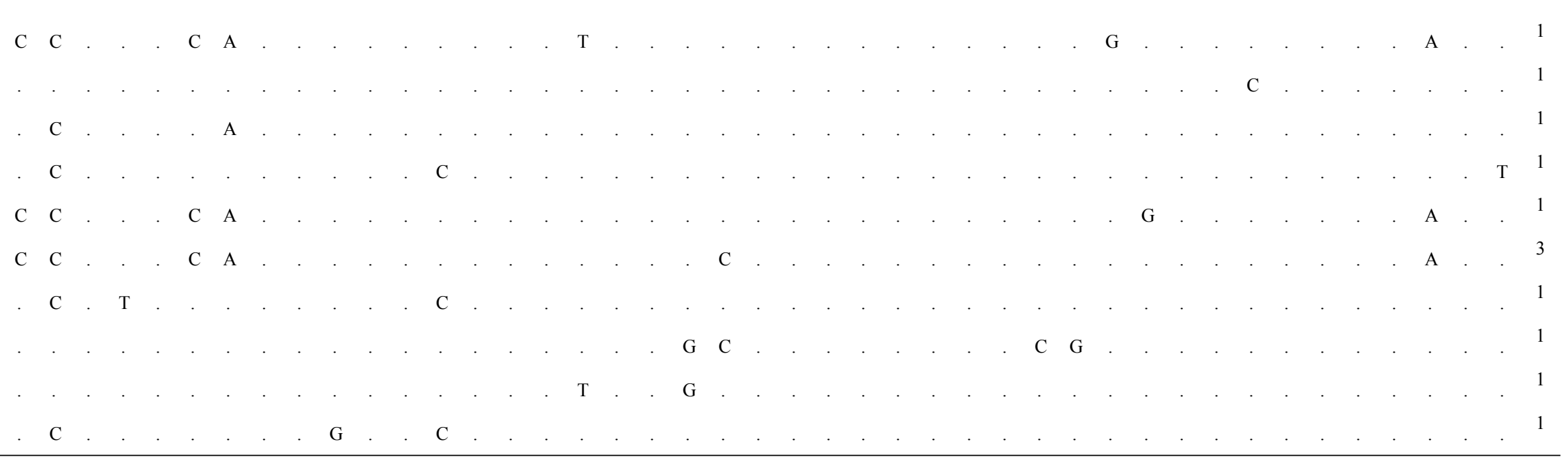

Note: $\mathrm{n}=$ number of observations of each haplotype 


\section{Table 2 (on next page)}

Genetic diversity of Tachypleus gigas in each locations

Notes: $\mathrm{n}=$ number of samples; $\mathrm{N} h=$ number of haplotype; $h=$ haplotype diversity; $\pi=$ nucleotide diversity 
1 Tabel 2

2 Genetic diversity of Tachypleus gigas in each locations

3

\begin{tabular}{lcccccc}
\hline Population & Code & A+T\% & $\mathrm{n}$ & $\mathrm{N} h$ & $h$ & $\pi$ \\
\hline Bintan & BT & 81.597 & 8 & 6 & 0.892 & 0.006 \\
Balikpapan & BP & 81.473 & 14 & 10 & 0.945 & 0.009 \\
Demak & DK & 81.568 & 16 & 6 & 0.783 & 0.004 \\
Madura & MD & 81.412 & 13 & 8 & 0.910 & 0.006 \\
Subang & SB & 81.548 & 20 & 11 & 0.926 & 0.005 \\
Ujung Kulon & UK & 81.434 & 20 & 12 & 0.942 & 0.005 \\
\hline Total & & & 91 & & 0.935 & 0,0064 \\
\hline
\end{tabular}

4

5 Notes: $\mathrm{n}=$ number of samples; $\mathrm{N} h=$ number of haplotype; $h=$ haplotype diversity; $\pi=$ nucleotide 6 diversity

7 


\section{Table $\mathbf{3}$ (on next page)}

Pairwise

Notes : $F_{\mathrm{ST}}$ value significantly different $(p<0.05)^{*} ; \mathrm{BT}=$ Bintan; $\mathrm{BP}=$ Balikpapan; $\mathrm{DK}=$ Demak; $\mathrm{MD}=$ Madura; $\mathrm{SB}=$ Subang; $\mathrm{UK}=$ Ujung Kulon 
$1 \quad$ Tabel 3

2 Pairwise $F_{\mathrm{ST}}$ between populations of Tachypleus gigas in six sampling locations

3

\begin{tabular}{lcccccc}
\hline & BT & BP & DK & MD & SB & UK \\
\hline BT & - & & & & & \\
BP & 0.05 & - & & & & \\
DK & 0.08 & 0.00 & - & & & \\
MD & 0.13 & 0.00 & 0.00 & - & & \\
SB & 0.11 & 0.01 & 0.00 & 0.00 & - & - \\
UK & 0.00 & 0.08 & 0.09 & $0.10^{*}$ & $0.10^{*}$ & - \\
\hline
\end{tabular}

4

Notes : $F_{\mathrm{ST}}$ value significantly different $(p<0.05) *$; $\mathrm{BT}=$ Bintan; $\mathrm{BP}=$ Balikpapan; $\mathrm{DK}=$ Demak; $\mathrm{MD}=$ Madura; $\mathrm{SB}=$ Subang; $\mathrm{UK}=$ Ujung Kulon 


\section{Table 4 (on next page)}

The analysis of molecular variation (AMOVA) that conducted based on the haplotype frequencies of Tachypleus gigas 
$1 \quad$ Tabel 4

2 The analysis of molecular variation (AMOVA) that conducted based on the haplotype frequencies

3 of Tachypleus gigas

4

\begin{tabular}{lcccc}
\hline $\begin{array}{l}\text { Source of } \\
\text { variation }\end{array}$ & d.f & $\begin{array}{c}\text { Percentage of } \\
\text { variation }\end{array}$ & $F_{\mathrm{ST}}$ & $p$-values \\
\hline $\begin{array}{l}\text { Among } \\
\text { populations }\end{array}$ & 5 & 4.77 & 0.04 & 0.006 \\
$\begin{array}{l}\text { Within } \\
\text { populations }\end{array}$ & 85 & 95.23 & \\
\hline Total & 90 & & & \\
\hline
\end{tabular}

5

6 


\section{Table 5 (on next page)}

Results of Tajima's $D$ and Fu's $F_{s}$ tests including associated $p$-values in all locations

Notes: $\mathrm{ns}=$ not significant 
1 Table 5:

2 Results of Tajima's $D$ and Fu's $F_{S}$ tests including associated $p$-values in all locations

3

\begin{tabular}{lcc}
\hline \multicolumn{1}{c}{ Population } & Tajima's $D$ & Fu's $F_{S}$ \\
\hline Bintan & $-0.646^{\mathrm{ns}}$ & $-0.608^{\mathrm{ns}}$ \\
Balikpapan & $0.601^{\mathrm{ns}}$ & $0.847^{\mathrm{ns}}$ \\
Demak & $0.325^{\mathrm{ns}}$ & $-2.941^{\mathrm{ns}}$ \\
Madura & $-0.875^{\mathrm{ns}}$ & $-1.532^{\mathrm{ns}}$ \\
Subang & $0.166^{\mathrm{ns}}$ & $-0.891^{\mathrm{ns}}$ \\
Ujung Kulon & $-0.318^{\mathrm{ns}}$ & $-3.865^{\mathrm{ns}}$ \\
\hline
\end{tabular}

4

5 Notes: $\mathrm{ns}=$ not significant 